\title{
Development of the Methodology for the Choice of Polygraphy Equipment for Printing on Cloth
}

\author{
VITALINA BABENKO \\ Dr. Sci. in Economics, Professor \\ Department of International E-Commerce and Hotel\&Restaurant Business \\ V.N. Karazin Kharkiv National University \\ 4 Svobody Sq., Kharkiv, 61022 \\ UKRAINE \\ http://orcid.org/0000-0002-4816-4579 \\ YEVHEN HRABOVSKYI \\ Department of Computer Systems and Technologies \\ Simon Kuznets Kharkiv National University of Economics \\ Kharkiv, Nauky Avenue, 9a \\ UKRAINE \\ http://orcid.org/0000-0001-7799-7249 \\ ANDRII IVASHURA \\ Department of Environmental Technologies, Ecology and Safety of Vital Activity \\ Simon Kuznets Kharkiv National University of Economics \\ Kharkiv, Nauky Avenue, 9a \\ UKRAINE \\ OLGA PROTASENKO \\ Department of Environmental Technologies, Ecology and Safety of Vital Activity \\ Simon Kuznets Kharkiv National University of Economics \\ Kharkiv, Nauky Avenue, 9a \\ UKRAINE
}

\begin{abstract}
The article provides a comparative analysis of the main types of printing on cloth. On the basis of analysis was revealed the meaning of the main stages for each type of printing and was systematized the used printing equipment. There are the main technical characteristics proposed for the selection of printing equipment. The technological and economic criteria for the choice of equipment for printing on cloth are examined in detail. There was carried out identification of the main criteria for the selection of equipment for printing on cloth by an expert assessment of technological and economic criteria with the assistance of operational printing centers' staff of Ukraine and Kazakhstan. There was developed a computer decision support system "the choice of equipment for printing on cloth" with local data synchronization using the Microsoft Sync Framework.
\end{abstract}

Key-Words: - printing on fabric, polygraphy equipment, criteria, technical characteristics, cloth.

Received: November 7, 2019. Revised: March 24, 2020. Accepted: May 5, 2020. Published: May 12, 2020.

\section{Introduction}

\subsection{The relevance of the topic "the choice of equipment for printing on cloth"}

As for today, the development of polygraphy has resulted in great demand for individualized advertising materials. Anyone can easily have business cards, booklets, flyers, letterheads, envelopes, t-shirts, and other promotional products. This type of service on the market resulted in the production of new printing equipment, as well as the emergence of new special types of printing. One of the most famous trends in the visual communications market is the usage of textile materials.

A variety of advertising products allows you to emphasize your individuality, to stand out from the competition and to maintain a positive image. A great way to express yourself is to draw a logo on flags and pennants, to make corporate banners, 
printing on T-shirts and corporate clothes. Therefore, you can also demonstrate to partners and potential clients not only the production capacity but also the creativity of your company. However, the choice of proper equipment for printing on the cloth is too complicated. This is due to the variety of printing methods on the cloth and the number of equipment on the market.

\section{Problem Formulation}

\subsection{Literature review}

The monograph [1] presents an analysis of modern printing methods used for printing on cloth. Key trends in the creation of printed products on cloth are structured in the research [2]. The crucial factor in the creation of $3 \mathrm{D}$ volumetric images was analyzed in a scientific article [3]. In the research [4], a study was made of the hydraulic properties of the printed surface. The influence of various factors on the quality of a printed pages are considered in studies $[5,6]$.

The economic and environmental aspects of the creation of printing products, including cloth, are analyzed in the article [7]. The work [8] provides an analysis of the restrictions of using offset printing. There are [9] the rheological properties of the compositions under conditions of printing on cloth are structured in the article. Adaptive image processing algorithms for printing on cloth are considered in studies [10].

The research [11-13] proposes an optimization model for creating an information system interface that can be used for automated control of printing processes on cloth. A toolkit for information support of the equipment selection process is proposed in studies [14, 15].

Mathematical methods that can be used to describe the process of choosing printing equipment are considered in studies $[16,17]$.

At the same time, specialized literature does not contain a holistic scientifically based methodology that would describe the process of the choice of printing equipment for printing on cloth.

The purpose of this research is to develop a methodology for the choice of equipment for printing on cloth.

\subsection{Research methodology}

The main way to obtain images on fabrics is traditionally screen printing or silk-screen printing. Screen printing is the oldest and most practical printing method.
The printing-technical and qualitative properties of the fabric (mesh) are determined by the material, the lineature (the number of mesh threads per centimeter of its length), the thickness of the stencil, the degree of openness of the mesh (the ratio of the total area of all cells to the total area of the mesh in percent).

Almost any type of fabric on which ink can polymerize is suitable for direct printing onto fabrics. In practice, this is any high-quality textiles used in advertising and promotion, as well as for ordinary clothes.

Another method of printing on fabrics is sublimation printing. This printing method is based on the process of sublimation - the process of transition of a solid substance into a gaseous one without a liquid phase.

The method of sublimation does not imply the transition of the entire ink layer from paper to fabric. It is based on the property of some dyes under the influence of temperature to pass into a gaseous state (sublimate). Dye molecules form a chemical bond with certain active groups of fiber molecules, therefore this method is applicable only to synthetic or mixed fabrics with a synthetic content of at least $60 \%$. There is no paint layer in its traditional sense, therefore, using this technology it is possible to obtain images only on white fabric.

The choice of screen printing is often determined by the fact that the equipment used practically does not impose restrictions on the print format.

Due to the variety of printing methods and types of printing equipment, it became difficult for workers in the field of operational printing to decide on one or another type of equipment for printing onto fabrics.

The scientific problem of this study is the lack of methods for selecting equipment for operational printing on fabric.

An applied problem is the lack of automation of the process of selecting equipment for operational printing on fabric.

To solve these problems, the article used such general scientific methods as systemic and structural analysis, which allowed to study the theoretical aspects and features of practical implementation of the process of printing on fabric. In particular, systematic and structural analysis were also used to analyze the main types of fabric printing, to study the main steps of the printing process and printing equipment for printing on fabric.

Mathematical methods and models were used in the construction of the technique of choosing the equipment for printing on the fabric, namely: the expert approach and matrix models were used to 
formulate a set of criteria for choosing the equipment for printing on the fabric.

Induction and deduction are used to investigate the specifics of tissue printing equipment;

An assessment of the consistency of expert opinions was carried out using the Kendall concordance coefficient.

The determination of all possible sets of equipment for creating a set that fully ensures the process of operational printing on fabric was carried out using the discrete programming method. To solve it one of the cutoff methods was applied - the Dalton-Llewelyn algorithm.

Development of a decision support system for the selection of equipment for printing on fabrics implemented using Visual Studio 2010 Professional Edition.

\section{Problem Solution}

The screen printing is used for printing:

1) on the fabric;

2) images on t-shirts;

3) on metal;

4) on various types of securities;

5) on plastic;

6) on toys;

7) on the packaging (plastic bags, plastic bags, etc.).

The advantages of screen printing:

1) a large selection of types of media for printing and inks;

2) low cost of print;

3) large size of the sealed area;

4) high quality printed imprint;

5) high image stability to external influences.

Disadvantages of screen printing:

1) requires lengthy prepress preparation;

2) printing of less than $100-500$ copies is disadvantageous;

3) dependence on the color of the picture (no more than 6-8 colors);

4) environmentally unsafe.

However, as a result of the development of digital printing methods, screen technology has become strong competitors

Plotters for printing on fabrics can use both special technologies (for example, electrostatic printing), as well as technologies well known from desktop printers - thermography, electrophotography, inkjet printing. Inkjet printing is a non-contact technology and is therefore well suited for direct printing on a wide variety of media.

Advantages of digital printing:

1) high print speed;

2) minimum image preparation time;
3) full color image;

4) low cost of print;

5) high resistance to external influences;

6) lack of harmful fumes, environmental friendliness.

Disadvantages of digital printing:

1) the high cost of printing equipment;

2) the high cost of impregnated fabrics;

3) limited selection of fabrics.

Another method of printing on fabrics is sublimation printing. This printing method is based on the process of sublimation - the process of transition of a solid substance into a gaseous one without a liquid phase.

Advantages of sublimation printing:

1) high resistance to external influences;

2) high image quality;

3) minimum image preparation time;

4) environmental friendliness.

Disadvantages of sublimation printing:

1) the ability to print only on white synthetic fabrics;

2) the high price of equipment and supplies;

3) slow output of photos;

4) the presence of an intermediate medium.

Thermal transfer requires the use of presses with a uniform distribution of temperature and pressure over the area of the plate, since otherwise the transition of the dyes will be uneven and the image will have uneven saturation in different places.

Inks for this type of printing are prepared by mixing concentrates of sublimation dyes with transparent binders that give them printing properties. The gamut of dyes consists of ten colors, including two fluorescent ones. They are mixed with a binder, while their concentration is $3-20 \%$, depending on the desired color intensity.

Advantages of thermal transfer:

1) the ability to transfer fine lines and small parts;

2) the ability to print on materials such as coarse linen, canvas, burlap, mesh fabrics;

3) high print speed;

4) low cost;

5) high resistance to external influences.

Disadvantages of thermal transfer:

1) the presence of an intermediate medium;

2) significant preparation time for printing;

3) small format of the printed surface

In thermal transfer printing, any fabric can serve as a printed material. And also the thermal transfer can be applied to materials that are not accessible for high-quality screen printing: coarse linen, canvas, burlap, mesh fabrics. 
A comparative analysis of the types of printing are presented in table 1 .

The analysis revealed the main stages for each type of print.

Table 1 An analysis of the types of printing

\begin{tabular}{|c|c|c|c|c|}
\hline $\begin{array}{l}\text { Criteria/ } \\
\text { Types of } \\
\text { printing }\end{array}$ & $\begin{array}{l}\text { Scren } \\
\text { printing }\end{array}$ & $\begin{array}{l}\text { Digital } \\
\text { prin } \\
\text { ting }\end{array}$ & $\begin{array}{l}\text { Sublima } \\
\text { tion } \\
\text { printing }\end{array}$ & $\begin{array}{l}\text { Trans } \\
\text { fer prin } \\
\text { ting }\end{array}$ \\
\hline $\begin{array}{l}\text { Type of } \\
\text { cloth }\end{array}$ & any & $\begin{array}{l}\begin{array}{l}\text { cotton } \\
\text { cloth } \\
\text { (cotton } \\
95 \% \\
100 \%)\end{array}-\end{array}$ & $\begin{array}{l}\text { synthetic } \\
\text { cloth } \\
\text { (polyester } \\
70 \% \text { ) }\end{array}$ & $\begin{array}{l}\text { any } \\
\text { (coarse } \\
\text { flax, } \\
\text { canvas, } \\
\text { burlap, } \\
\text { mesh } \\
\text { fabrics) }\end{array}$ \\
\hline Speed & high & high & low & medium \\
\hline $\begin{array}{l}\text { Image } \\
\text { prepara } \\
\text { tion time }\end{array}$ & 5 hours & $\begin{array}{l}5 \\
\text { minutes }\end{array}$ & 5 minutes & 5 minutes \\
\hline $\begin{array}{l}\text { Color of } \\
\text { material }\end{array}$ & any & any & $\begin{array}{l}\text { only } \\
\text { white }\end{array}$ & any \\
\hline $\begin{array}{l}\text { Print } \\
\text { quality }\end{array}$ & high & medium & high & high \\
\hline $\begin{array}{l}\text { Size of } \\
\text { the } \\
\text { printing } \\
\text { surface }\end{array}$ & big & medium & big & $\begin{array}{l}\text { small (no } \\
\text { more than } \\
\text { A4) }\end{array}$ \\
\hline $\begin{array}{l}\text { Colori } \\
\text { fic of } \\
\text { image }\end{array}$ & $\begin{array}{l}\text { no more } \\
\text { than } \\
5-8 \\
\text { colors }\end{array}$ & $\begin{array}{l}\text { no } \\
\text { restric- } \\
\text { tion }\end{array}$ & $\begin{array}{l}\operatorname{mix} 12 \\
\text { colors }\end{array}$ & $\begin{array}{l}\text { no } \\
\text { restriction }\end{array}$ \\
\hline $\begin{array}{l}\text { Printing } \\
\text { gradients } \\
\text { and full- } \\
\text { color } \\
\text { photo } \\
\text { graphs }\end{array}$ & $\begin{array}{l}\text { partially } \\
\text { possible }\end{array}$ & possible & possible & impossible \\
\hline $\begin{array}{l}\text { Printing } \\
\text { on black } \\
\text { and } \\
\text { color } \\
\text { cloth }\end{array}$ & + & + & - & + \\
\hline $\begin{array}{l}\text { Printing } \\
\text { with } \\
\text { special } \\
\text { inks } \\
\end{array}$ & + & - & - & + \\
\hline
\end{tabular}

Based on the analysis of types of printing, three main stages can be distinguished for each type: prepress, printing and post-print processing.

Screen printing: the prepress stage includes the receipt of a printing form or screen.
The next step in the process of screen printing is direct printing. The made printing plate is fixed in the printing machine or on the machine. Paint is loaded on top of it and the squeegee is lowered, which is a rigid holder with a rectangular plate fixed in it. When the squeegee moves along the grid, ink is forced through the cells, and the ink is applied to the surface to be printed.

Postpressing includes drying of prints. Several methods are known for drying screen prints. The specificity of their drying is due to the fact that a thick layer of ink is applied to the prints, far exceeding the thickness of the layer obtained by other printing methods. Drying such prints requires more energy and time.

Digital printing: when printing on fabric in this way at the prepress stage, the material is impregnated with a special composition that prevents ink from spreading through the fibers of the fabric as it is absorbed.

This ensures high definition images. The structure of woven materials suggests the possibility of penetration of dyes to a rather large depth, therefore, depending on the thickness and texture of the fabric, it is possible to stain its back side.

Sublimation printing: at the prepress stage, using the sublimation printing method, first you need to print on the sublimation paper the necessary image, previously flipped inverted.

The peculiarity of sublimation paper is that it does not absorb ink, allowing them to be almost completely transferred to the fabric. The next step is to transfer the image to the fabric. The print obtained on sublimation paper is combined with the front side and the front side of the fabric.

For transfer, depending on the shape and size of the product, a flat or calendered thermal press is used. This device, when exposed to temperature and pressure, transfers the image to the fabric, as a result of which the dye is embedded in the structure of the fibers and is firmly fixed in them.

Transfer printing: for this type of printing, the first step is the manufacture of thermal films (thermal transfer transfer).

After the transfer has been received, the printing stage begins. The transfer is superimposed on the fabric surface with glue down without using intermediate mounting films, and the heat-resistant substrate on top protects the transfer from damage and holds the image elements together.

The results are presented in table 2 .

Table 2 The main stages for various types of printing on cloth 


\begin{tabular}{|c|c|c|c|}
\hline $\begin{array}{l}\text { Type of } \\
\text { printing/ } \\
\text { Stage }\end{array}$ & Pre-press & Printing & $\begin{array}{l}\text { Post } \\
\text { printing } \\
\text { processing }\end{array}$ \\
\hline $\begin{array}{l}\text { screen } \\
\text { printing } \\
\text { (silk } \\
\text { screen } \\
\text { printing) }\end{array}$ & $\begin{array}{l}\text { 1.preparation } \\
\text { of } \\
\text { photoforms. } \\
\text { The output of } \\
\text { the film in a } \\
\text { 1: } 1 \text { scale and } \\
\text { its exposure; } \\
\text { 2. washing of } \\
\text { the printing } \\
\text { form } \\
\text { (stencil). } \\
\text { The } \\
\text { correspondin } \\
\text { g number of } \\
\text { stencils is } \\
\text { displayed for } \\
\text { each color }\end{array}$ & $\begin{array}{l}\text { 1.the } \\
\text { location of } \\
\text { the } \\
\text { printing } \\
\text { surface on } \\
\text { the table, } \\
\text { the } \\
\text { imposition } \\
\text { of a stencil } \\
\text { on it; } \\
\text { applying } \\
\text { the } \\
\text { required } \\
\text { amount of } \\
\text { ink. }\end{array}$ & 1.drying \\
\hline $\begin{array}{l}\text { digital } \\
\text { printing } \\
\text { (direct- } \\
\text { printing) }\end{array}$ & $\begin{array}{l}\text { preparing the } \\
\text { cloth for } \\
\text { printing. The } \\
\text { cloth is } \\
\text { impregnated } \\
\text { with a special } \\
\text { composition } \\
\text { that prevents } \\
\text { ink from } \\
\text { spreading } \\
\text { over the } \\
\text { fibers of the } \\
\text { cloth. }\end{array}$ & $\begin{array}{l}\text { 1. printing } \\
\text { on inkjet } \\
\text { printer } \\
\text { with } \\
\text { special ink. } \\
\text { Ink must } \\
\text { be suitable } \\
\text { for the } \\
\text { type of } \\
\text { printing } \\
\text { surface }\end{array}$ & $\begin{array}{l}\text { 1.If natural } \\
\text { cloth is } \\
\text { used, then } \\
\text { there are } \\
\text { active and } \\
\text { acid dyes } \\
\text { used for } \\
\text { them. In } \\
\text { this case, it } \\
\text { is necessary } \\
\text { to fix the } \\
\text { image after } \\
\text { printing } \\
\text { with } \\
\text { superheated } \\
\text { steam; the } \\
\text { image, the } \\
\text { fabric must } \\
\text { be washed }\end{array}$ \\
\hline $\begin{array}{l}\text { sublimatio } \\
\text { n printing } \\
\text { (for } \\
\text { synthetic } \\
\text { white } \\
\text { cloth } \\
\text { only) }\end{array}$ & $\begin{array}{l}\text { 1. The image } \\
\text { is digitally } \\
\text { applied to } \\
\text { paper using a } \\
\text { special } \\
\text { printer. }\end{array}$ & $\begin{array}{l}\text { The image } \\
\text { from the } \\
\text { paper is } \\
\text { transferred } \\
\text { to a } \\
\text { synthetic } \\
\text { fabric } \\
\text { using a } \\
\text { thermal } \\
\text { press }\end{array}$ & $\begin{array}{l}\text { Finishing } \\
\text { work of the } \\
\text { product } \\
\text { itself or } \\
\text { packaging } \\
\text { may be } \\
\text { performed } \\
\text { at the post- } \\
\text { printing } \\
\text { stage }\end{array}$ \\
\hline $\begin{array}{l}\text { transfer } \\
\text { printing }\end{array}$ & $\begin{array}{l}\text { cut thermal } \\
\text { films on a } \\
\text { plotter in a } \\
\text { mirror image. }\end{array}$ & $\begin{array}{l}\text { the transfer } \\
\text { is applied } \\
\text { to the } \\
\text { fabric with } \\
\text { glue down. }\end{array}$ & $\begin{array}{l}\text { product } \\
\text { cooling and } \\
\text { substrate } \\
\text { removal }\end{array}$ \\
\hline
\end{tabular}

Equipment for operational printing on cloth was divided at the printing stage as a result of systematization (table 3).

As the main technical characteristics for the choose of printing equipment should be highlighted: type of the printing surface;

size of the printed area;

color of the printed areas;

printing speed;

colorific of printing;

the ability to print with special inks.

The specified characteristics are taken into account in the process of the choice equipment. Technological features of operational printing on cloth are taken into account at a particular enterprise and make up the corresponding group of indicators "technological criteria for the choice of equipment".

Table 3 Systematization of equipment used

\begin{tabular}{|c|c|c|c|}
\hline $\begin{array}{l}\text { Types of } \\
\text { printing/ } \\
\text { Stage }\end{array}$ & Pre-press & Printing & $\begin{array}{l}\text { Post } \\
\text { printing } \\
\text { Process } \\
\text { sing } \\
\end{array}$ \\
\hline $\begin{array}{l}\text { screen } \\
\text { printing }\end{array}$ & $\begin{array}{l}\text { 1.copy } \\
\text { frames; } \\
\text { 2.exposure } \\
\text { devices } \\
\text { 3.intermedi } \\
\text { ate IR } \\
\text { drying, } \\
\text { quartz } \\
\text { drying } \\
\end{array}$ & $\begin{array}{l}\text { 1.hand- } \\
\text { operated } \\
\text { press } \\
\text { 2.half- } \\
\text { automatic } \\
\text { (automatic) } \\
\text { press }\end{array}$ & $\begin{array}{l}\text { 1.multi- } \\
\text { tier } \\
\text { drying } \\
\text { racks } \\
\text { 2.tunnel } \\
\text { drying }\end{array}$ \\
\hline $\begin{array}{l}\text { digital } \\
\text { printing }\end{array}$ & $\begin{array}{l}\text { equipment } \\
\text { not used }\end{array}$ & $\begin{array}{l}\text { 1.direct } \\
\text { inkjet } \\
\text { printers } \\
\text { with a } \\
\text { built-in ink } \\
\text { curing } \\
\text { system } \\
\text { 2.modules } \\
\text { for fixing } \\
\text { ink. }\end{array}$ & $\begin{array}{l}\text { equipme } \\
\text { nt not } \\
\text { used }\end{array}$ \\
\hline $\begin{array}{l}\text { sublimatio } \\
\text { n printing }\end{array}$ & $\begin{array}{l}\text { 1.inkjet } \\
\text { piezo } \\
\text { printer for } \\
\text { printing on } \\
\text { sublimation } \\
\text { paper }\end{array}$ & $\begin{array}{l}\text { 1.die heat } \\
\text { press } \\
\text { 2.calender } \\
\text { thermal } \\
\text { press }\end{array}$ & $\begin{array}{l}\text { equipme } \\
\text { nt not } \\
\text { used }\end{array}$ \\
\hline $\begin{array}{l}\text { transfer } \\
\text { printing }\end{array}$ & $\begin{array}{l}\text { 1.plotter } \\
\text { for cutting } \\
\text { thermal } \\
\text { films }\end{array}$ & $\begin{array}{l}\text { 1. die heat } \\
\text { press } \\
\text { 2.calender } \\
\text { thermal } \\
\text { press }\end{array}$ & $\begin{array}{l}\text { equipme } \\
\text { nt not } \\
\text { used }\end{array}$ \\
\hline
\end{tabular}

The group of technological criteria is:

the printing method: screen printing; digital printing; sublimation printing; transfer printing;

the type of cloth: synthetic; natural; any material; 
the format of the printing surface: wide format (greater than $400 \mathrm{~mm}$ ); standard formats (A0, A1, A2, etc.);

the color of the printing surface: white; color;

print resolution: $1200 \mathrm{dpi} ; 1440 \mathrm{dpi}$;

print speed: law (up to $80 \mathrm{~km} /$ day); medium (80-260 km / day); high (from $260 \mathrm{~km} /$ day);

equipment dimensions: small (up to $400 \mathrm{~cm}$ ); medium $(400-1000 \mathrm{~cm})$; large (more than $1000 \mathrm{~cm})$;

the ability to print gradients, full-color photographs: partially possible; possible; impossible;

the ability to print with special inks: possible; impossible

a) consumables: paint; mesh for stencil; sublimation paper; flex or flock.

The management of printing companies selects a particular machine among a lot of options for printing equipment, taking into account such general conditions as the company's position on the market and the amount of investment necessary to purchase equipment for printing on cloth. The meaning of the following criteria should be compared at the time of choosing equipment:

1) the stability of orders for the production of printing products (determines the necessary productivity of equipment and the flexibility of its use);

2) the cost of equipment and the service life, which determine the amount of depreciation, as well as the cost of routine maintenance and repair (spare parts, consumables, etc.);

3) an affordable way to purchase the selected equipment (determines the cost of printing).

These indicators take into account the economic situation of the enterprise and constitute the corresponding group of indicators - "economic criteria for the choice of equipment".

A group of economic criteria is:

1) the cost of equipment:

1.1) low cost ( $0-60$ thousand UAH);

1.2) average cost (60-110 thousand $\mathrm{UAH})$;

1.3) high cost (over 110 thousand UAH);

2) method of acquiring equipment: for cash; on credit; for rent;

3 ) the frequency of orders: mass; serial single;

4) qualifications and work experience of staff at the enterprise, which must ensure the functioning of new equipment:

4.1) high-level qualifications (5-6 category) and significant work experience (more than 2-3 years);

4.2) medium-level qualification (2-4 category) and significant work experience (more than 2-3 years);
4.3) medium-level qualification (2-4 category) and insignificant work experience ( $0.5-2$ years);

4.4) medium-level qualification ( $2-4$ category), without work experience;

4.5) medium or low level of qualification (2-4 category), without work experience (up to 0.5 years or a trial period);

5) planning costs for in-line maintenance and repair of equipment:

5.1) planned in a large amount $(5-15 \%$ of the cost of equipment);

5.2) planned on average (up to $5 \%$ of the cost of equipment);

5.3) unplanned;

6) the level of automation at the enterprise: fully automated; most are automated; partially automated; the minimum level of automation; lack of automation.

A certain set of criteria will allow a comprehensive assessment of possible alternatives for the choice of equipment for printing on cloth.

An expert assessment of technological and economic criteria was carried out to identify the main criteria for the choice of equipment for printing on cloth,

The survey involved 11 experts - employees of the following operational printing centers: SophieStyle (Kazakhstan); ProfDesign (Kharkiv); Polygraphy "Clone" (Kharkiv); AbcDocPrint (Kharkiv); Wizart (Kyiv); Printing House (Kharkiv); VRM (Kyiv); Advertising Studio PranaPrint (Kharkiv); Colors of Life (Kharkiv); Print Master (Kharkiv).

The choice can be justified by the fact that they have skills and knowledge in the field of operational printing on cloth.

There were provided the following criteria for the choice of equipment for printing on cloth for ranking:

the type of printing;

the type of cloth;

size of the printed area;

color of the printed areas;

print resolution;

print speed;

the dimensions of the equipment;

the ability to print gradients, full color photographs;

the ability to print with special inks;

consumables;

the cost of equipment;

the method of acquiring equipment;

the frequency of orders; 
qualifications and work experience of staff at the enterprise, which should ensure the operation of new equipment;

planning costs for in-line maintenance and repair of equipment;

the level of automation at the enterprise.

Table 4 was generated based on the results of the experts' work. It contains information on the criteria ranked on a scale from 1 to 16.

Table 5 was built based on the data in table 4 , including columns with the sum of the ranks and the variance in ranks (deviation from the average) for each factor.

Table 4 Criteria ranking

\begin{tabular}{|l|l|l|l|l|l|l|l|l|l|l|l|}
\hline $\begin{array}{l}\text { Experts/ } \\
\text { Criteria }\end{array}$ & e1 & e2 & e3 & e4 & e5 & e6 & e7 & $\mathbf{e 8}$ & $\mathbf{e 9}$ & $\mathbf{e 1 0}$ & $\mathbf{e 1 1}$ \\
\hline c 1 & 16 & 14 & 15 & 16 & 14 & 14 & 16 & 14 & 16 & 14 & 14 \\
\hline c 2 & 9 & 10 & 8 & 7 & 8 & 13 & 11 & 10 & 11 & 13 & 12 \\
\hline c 3 & 12 & 8 & 13 & 12 & 3 & 12 & 9 & 11 & 9 & 11 & 10 \\
\hline c 4 & 8 & 7 & 7 & 6 & 7 & 9 & 10 & 9 & 10 & 9 & 9 \\
\hline c 5 & 1 & 13 & 10 & 9 & 13 & 8 & 7 & 8 & 6 & 7 & 7 \\
\hline c 6 & 11 & 6 & 11 & 11 & 6 & 7 & 8 & 7 & 7 & 10 & 11 \\
\hline c 7 & 6 & 5 & 6 & 5 & 5 & 6 & 5 & 6 & 5 & 6 & 5 \\
\hline c 8 & 7 & 11 & 5 & 4 & 11 & 5 & 6 & 5 & 4 & 5 & 6 \\
\hline c 9 & 2 & 4 & 3 & 2 & 4 & 3 & 1 & 1 & 1 & 2 & 1 \\
\hline c10 & 5 & 15 & 4 & 8 & 15 & 4 & 4 & 3 & 8 & 4 & 8 \\
\hline c 11 & 15 & 16 & 16 & 14 & 16 & 16 & 15 & 16 & 15 & 15 & 16 \\
\hline c 12 & 14 & 1 & 14 & 15 & 12 & 15 & 14 & 15 & 14 & 16 & 15 \\
\hline c 13 & 13 & 9 & 12 & 13 & 9 & 10 & 13 & 13 & 13 & 8 & 4 \\
\hline c 14 & 4 & 3 & 2 & 3 & 1 & 1 & 3 & 4 & 3 & 1 & 3 \\
\hline c 15 & 3 & 2 & 1 & 1 & 2 & 2 & 2 & 2 & 2 & 3 & 2 \\
\hline c 16 & 10 & 12 & 9 & 10 & 10 & 11 & 12 & 12 & 12 & 12 & 13 \\
\hline
\end{tabular}

The deviation from the average is calculated by one of the formulas:

$\Delta_{i}=\sum_{j=1}^{m} r_{i j}-\frac{\sum_{i=1}^{n} \sum_{j=1}^{m} r_{i j}}{n}$ $\mathrm{n}$ - number of factors compared.

$$
\Delta_{\mathrm{i}}=\sum_{\mathrm{j}=1}^{\mathrm{m}} \mathrm{r}_{\mathrm{ij}}-\frac{\mathrm{m}(\mathrm{n}+1)}{2}
$$

where $\mathrm{m}$ - experts' number;

$\mathrm{n}$ - number of factors compared.

Table 5 Rank matrix

\begin{tabular}{|c|c|c|c|c|c|c|c|c|c|c|c|c|c|}
\hline $\begin{array}{c}\text { Exper } \\
\text { ts/ } \\
\text { Criter } \\
\text { ia }\end{array}$ & $\mathbf{e 1}$ & $\mathbf{e 2}$ & $\mathbf{e 3}$ & $\mathbf{e 4}$ & $\mathbf{e 5}$ & $\mathbf{e 6}$ & $\mathbf{e} 7$ & $\mathbf{e 8}$ & $\mathbf{e 9}$ & $\mathbf{e 1 0}$ & $\mathbf{e 1 1}$ & $\sum$ & $\Delta$ \\
\hline c 1 & 16 & 14 & 15 & 16 & 14 & 14 & 16 & 14 & 16 & 14 & 14 & 163 & 69,5 \\
\hline c 2 & 9 & 10 & 8 & 7 & 8 & 13 & 11 & 10 & 11 & 13 & 12 & 112 & 18,5 \\
\hline c 3 & 12 & 8 & 13 & 12 & 3 & 12 & 9 & 11 & 9 & 11 & 10 & 110 & 16,5 \\
\hline c 4 & 8 & 7 & 7 & 6 & 7 & 9 & 10 & 9 & 10 & 9 & 9 & 91 & $-2,5$ \\
\hline c 5 & 1 & 13 & 10 & 9 & 13 & 8 & 7 & 8 & 6 & 7 & 7 & 89 & $-4,5$ \\
\hline c 6 & 11 & 6 & 11 & 11 & 6 & 7 & 8 & 7 & 7 & 10 & 11 & 95 & 1,5 \\
\hline c 7 & 6 & 5 & 6 & 5 & 5 & 6 & 5 & 6 & 5 & 6 & 5 & 60 & - \\
\hline c 8 & 7 & 11 & 5 & 4 & 11 & 5 & 6 & 5 & 4 & 5 & 6 & 69 & - \\
24,5 \\
\hline c 9 & 2 & 4 & 3 & 2 & 4 & 3 & 1 & 1 & 1 & 2 & 1 & 24 & - \\
69,5
\end{tabular}

where $\mathrm{m}$ - experts' number; 
Then, there was assessed the consistency of expert opinions. For this, the Kendall concordance coefficient is calculated [17].

$K=\frac{12 S}{m^{2}\left(n^{3}-n\right)}$

where $\mathrm{S}=\sum_{\mathrm{i}=1}^{\mathrm{n}} \Delta_{\mathrm{i}}^{2}-$ sum of squared rank differences.

It will be better if the concordance coefficient is closer to 1 .

Let's find the sum of the squares of the difference of ranks $(\mathrm{S})$ :

$$
\begin{gathered}
S=(76,5)^{2}+(69,5)^{2}+(51,5)^{2}+(29,5)^{2}+ \\
+(23,5)^{2}+(18,5)^{2}+(16,5)^{2}+(1,5)^{2}+ \\
+(-4,5)^{2}+(-15,5)^{2}+(-24,5)^{2}+(-33,5)^{2}+ \\
+(-65,5)^{2}+(-69,5)^{2}+(-71,5)^{2}=31595,97 \\
S=31595,97
\end{gathered}
$$

Calculate the coefficient of concordance:

$\mathrm{K}=\frac{12 \times 31595.97}{11^{2}\left(16^{3}-16\right)}=\frac{379151.64}{493680}=0.768 \approx 0.77$

If $\mathrm{K}<0,2-0,4$, then the consistency of expert opinions is weak. If $\mathrm{K}>0.6-0.8$, the consistency is strong. From the data obtained, it can be concluded that in this case, the coefficient of concordance is 0.77, which indicates a strong consistency of experts.

Based on the analysis of the expert assessment conducted, it is proposed to consider the main criteria with $\Delta>0$. When choosing equipment for the center for operational printing, the main parameters will be:

factor 11 - the cost of equipment $(\Delta=76,5)$;

factor 1 - the type of printing $(\Delta=69,5)$;

factor 12 - purchase method $(\Delta=51,5)$;

factor 16 - the level of automation at the enterprise $(\Delta=29,5)$;

factor 13 - the frequency of orders $(\Delta=23,5)$;

factor 2 - the type of cloth $(\Delta=18,5)$;

factor 3 - size of the printed area $(\Delta=16,5)$;

factor 6 - printing speed $(\Delta=1,5)$.

The choice of equipment according to the given values is presented after determining these parameters. It is necessary to determine all possible sets of equipment to create a set that fully ensures the process of operational printing on cloth if the amount that can be spent on the purchase of equipment is known.
Mathematical statement of the problem:

$f_{j}(x)=\sum_{i=1}^{7} a_{i j} x_{i} \rightarrow \min , j=\overline{1,4}$

where $\mathrm{fj}$ - the cost of a set of equipment for the $\mathrm{j}$ - type of printing;

$\mathrm{xi}$ - the cost of one equipment;

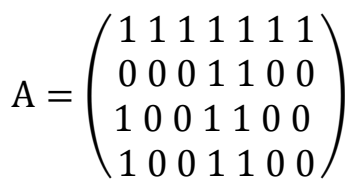

$$
\begin{aligned}
& \mathrm{f}_{\mathrm{j}}>0 \\
& \mathrm{f}_{\mathrm{j}} \leq \mathrm{C} \\
& \mathrm{x}_{\mathrm{i}} \in \mathrm{N}_{\mathrm{i}}
\end{aligned}
$$

where $\mathrm{A}$ - equipment requirements matrix for each type of print;

$\mathrm{xi}$ - the cost of one equipment;

$\mathrm{C}$-sum of money that can be spent on the purchase of equipment;

$\mathrm{Ni}$ - many values of equipment costs.

This task is a discrete programming task. One of the cutting methods can be applied to solve it - the Dalton-Llewelyn algorithm. The general scheme of cut-off methods consists in the transition from solving the problem of integer (discrete) linear programming $-\langle\Omega ц \mathrm{~F}-$ tasks» to solving a sequence of linear programming problems $-\langle\Omega \mathrm{kF}-$ tasks», $\mathrm{k}=0,1,2, \ldots$.

\section{Experimental}

Method steps are:

1) systematization of equipment for operational printing on fabric;

2) the formation of many criteria for the selection of equipment for operational printing on fabric;

3 ) the creation of a database of equipment based on the established criteria;

4) the formation of a database of experts and verification of the consistency of expert opinions when ranking criteria;

5) the formation of a list of primary and secondary criteria;

6) selection from the database of sets of equipment that meet the basic criteria;

7) selection from the results of stage 5 sets of equipment that meet secondary criteria.

Let 200,000 UAH be allocated for the purchase of equipment. Then the objective function and restrictions for digital printing will look like: 


$$
\begin{gathered}
\mathrm{f}(\mathrm{x})=\mathrm{x}_{1}+\mathrm{x}_{2} \rightarrow \min \\
\mathrm{x}_{1}+\mathrm{x}_{2}>0 \\
\mathrm{x}_{1}+\mathrm{x}_{2} \leq 200000 \\
\mathrm{x}_{1} \in\{144568 ; 113140 ; 247000\} \\
\mathrm{x}_{2} \in\{47158 ; 49077 ; 50732\}
\end{gathered}
$$

To solve this problem, such $\mathrm{x} 1$ and $\mathrm{x} 2$ are selected at which all restrictions will be satisfied, and the value of the objective function will tend to a

\begin{tabular}{|c|c|c|c|}
\hline \multirow{2}{*}{$\mathbf{x}_{1}$} & \multirow{2}{*}{$\mathbf{x}_{2}$} & \multicolumn{2}{|r|}{ If } \\
\hline & & $\mathbf{x}_{1}+\mathbf{x}_{2}>\mathbf{0}$ & $x_{1}+x_{2}<=200000$ \\
\hline 144568 & \multirow{3}{*}{47185} & 191753 & true \\
\hline 113140 & & 160325 & true \\
\hline 247000 & & 294185 & false \\
\hline 144568 & \multirow{3}{*}{49077} & 193645 & true \\
\hline 113140 & & 162217 & true \\
\hline 247000 & & 296077 & false \\
\hline 144568 & \multirow{3}{*}{50732} & 195300 & true \\
\hline 113140 & & 163872 & true \\
\hline 247000 & & 297732 & false \\
\hline
\end{tabular}
minimum. The calculation of this task is presented in table 6.

Table 6 Calculation of the cost of equipment for digital printing on fabric

Among the many options for printing equipment, the management of printing companies selects a particular machine, taking into account such general conditions as the company's position on the market and the amount of investment necessary to purchase equipment for printing on fabric.

Basically, the management of printing enterprises when choosing equipment compares the meaning of such criteria:

1) stability of the order for the production of printing products (determines the necessary productivity of the equipment and the flexibility of its use);

2) the cost of equipment and the service life, which determine the amount of depreciation, as well as the cost of routine maintenance and repair (spare parts, consumables, etc.);
3) an affordable way to purchase the selected equipment (determines the cost of printing).

As a result of the solution, six pieces of equipment were obtained that met the conditions of the task. The result is presented in table 7 .

Table 7 Calculation result

\begin{tabular}{|c|l|l|}
\hline $\begin{array}{c}\text { Cost, } \\
\mathbf{\$}\end{array}$ & $\begin{array}{l}\text { Digital Printing } \\
\text { Machines }\end{array}$ & $\begin{array}{l}\text { Ink Curing } \\
\text { Modules }\end{array}$ \\
\hline 5950 & DTX-40 & $\begin{array}{l}\text { Rimslow } \\
\text { STEAM-X } \quad 1850 \\
\text { ECOM }\end{array}$ \\
\hline 6021 & DTX-40 & $\begin{array}{l}\text { Rimslow } \\
\text { STEAM-X 2000 } \\
\text { ECOM }\end{array}$ \\
\hline 6100 & DTX-40 & $\begin{array}{l}\text { Rimslow } \\
\text { STEAM-X 2200 } \\
\text { ECOM }\end{array}$ \\
\hline 7117 & Azon TEX Pro & $\begin{array}{l}\text { Rimslow } \\
\text { STEAM-X 1850 } \\
\text { ECOM }\end{array}$ \\
\hline 7187 & Azon TEX Pro & $\begin{array}{l}\text { Rimslow } \\
\text { STEAM-X 2000 } \\
\text { ECOM }\end{array}$ \\
\hline 7249 & Azon TEX Pro & $\begin{array}{l}\text { Rimslow } \\
\text { STEAM-X 2200 } \\
\text { ECOM }\end{array}$ \\
\hline
\end{tabular}

Thus, as a result of solving such a problem, it is possible to determine the optimal cost of equipment based on the available amount of funds.

As a result of the software implementation of the proposed methodology, a decision support system (DSS) "Choosing equipment for printing on fabric" (Fig. 1) was developed. To implement the prototype program, Visual Studio 2010 Professional Edition was chosen as a toolkit.

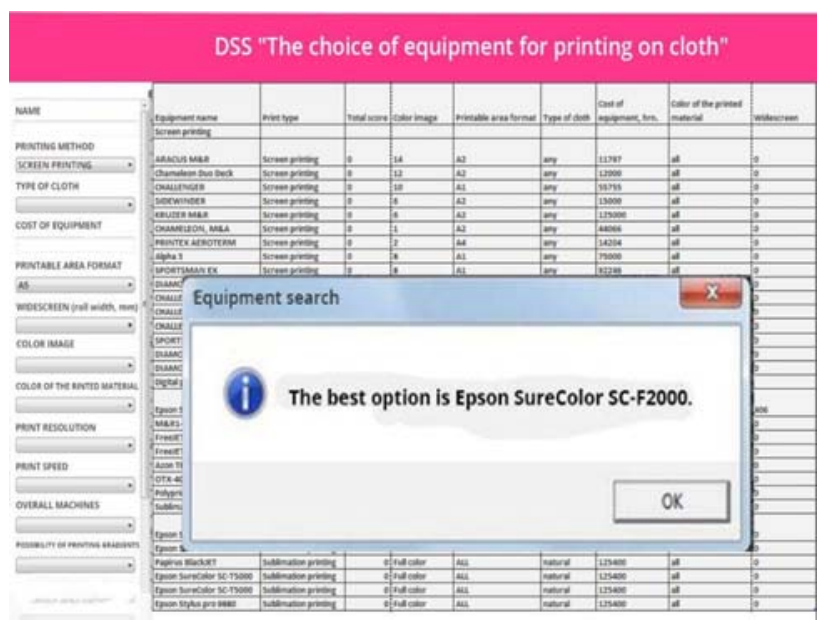

Fig.1 DSS interface "The choice of equipment for printing on cloth" 
Local data was synchronized using the Microsoft Sync Framework. To create this system, C \# and Visual Basic were serialized. XML serialization was also used. In XML serialization, open fields and object properties or parameters and return values of methods are serialized into an XML stream in accordance with a special document written in XSD (XML Schema Definition Language). XML serialization results in strongly typed classes with public properties and fields that are converted to XML format. The System.Xml.Serialization namespace contains the classes needed to serialize and deserialize XML. XmlSerializer was chosen to preserve the state of the object, since it is best suited for transferring complex structures when it is necessary to present data in a readable format, and does not need to depend on the platform, programming language, etc.

\section{Conclusion}

The article provides a comparative analysis of the main types of printing on cloth. The analysis criteria were: type of cloth, print speed, time to prepare the image, color of the material, print quality, size of the printed surface, color of the image, as well as the availability of the ability to print gradients and fullcolor photographs, print on black and color cloth, print with special inks. The analysis made it possible to identify the meaning of the main stages for each type of printing and to systematize the printing equipment used.

The main technical characteristics for the selection of printing equipment are proposed - the type of material to be printed, the format of the printed area, the color of the printed surface, print speed, colorific of printing, the ability to print with special inks. The technological and economic criteria for the choice of equipment for printing on cloth are examined in detail. Identification of the main criteria for the choice of equipment for printing on the cloth was carried out by an expert assessment of technological and economic criteria with the assistance of an expert staff of operational printing centers of Ukraine and Kazakhstan. An assessment was made of the consistency of expert opinions based on the use of the Kendall concordance coefficient.

The practical result of the proposed methodology is the computer decision support system "The choice of equipment for printing on cloth" with local data synchronization using the Microsoft Sync Framework.

\section{References:}

[1] Khadzhynova S., Jakucewicz S. Sposoby drukowania cyfrowego: Monografie, Łódź: Wydawnictwo Politechniki Łódzkiej, 242 p, 2016. ISBN 978-83-7283754-7

[2] Mulisch M., Tissue-Printing. Springer, 40 p., 2014. DOI: 10.1007/978-3-658-03867-0

[3] Hrabovskyi Y., Brynza N, Vilkhivska O. Development of information visualization methods for use in multimedia applications. EUREKA: Physics and Engineering, No.1, 2020, pp. 3 - 17. DOI: $10.21303 / 2461-4262.2020 .001103$

[4] Aslannejad H., Hassanizadeh S.M. Study of hydraulic properties of uncoated paper: image analysis and porescale modeling. Transp. Porous Media, No.120, 2017, pp. 67-81. DOI: https://doi.org/10.1007/s11242-0170909-x

[5] Sousa S., Sousa A.M., Reis B., Ana Ramos A. Influence of Binders on Inkjet Print Quality. Materials Science, 2014, Vol. 20 (2), Issue 1. pp. 55-60. doi: https://doi.org/10.5755/j01.ms.20.1.1998

[6] Zhan Y., Liu Z., Cao Y., Li R., Jing Y. Impact of Binder Composition on Inkjet Printing Paper. BioResources, Vol. 10 (1), 2015, pp. 1462-1476. doi: 10.15376/biores.10.1.1462-1476

[7] Małdziński L., Tacikowski J. Concept of an economical and ecological process of gas nitriding of steel. HTM Härtereitechnische Mitteilungen, T. 61, No.6, 2006, pp. 296-302.

[8] Rossitza, S. Offset Printing without Isopropyl Alcohol in Damping Solution. Energy Procedia, Vol. 74, 2015, pp. 690-698. DOI:10.1016/j.egypro.2015.07.804

[9] Krasinskyi V., Suberlyak O., Viktoria A., Jachowicz T. Rheological Properties of Compositions Based on Modified Polyvinyl Alcohol. Advances in Science and Technology Research Journal, Vol. 11 (3), 2017, pp. 304-309 doi: https://doi.org/10.12913/22998624/76584

[10] Safonov I., Adaptive Image Processing Algorithms for Printing. Springer, 2018. 304 p. DOI: 10.1007/978981-10-6931-4

[11] Hrabovskyi Y., Fedorchenko V., Development of the optimization model of the interface of multimedia edition. EUREKA: Physics and Engineering, No.3, 2019, pp. 3 - 12. doi: 10.21303/2461-4262.2019.00902

[12] Babenko, V., Nakisko, O., Latynin, M., Rudenko, S., Lomovskykh, L., and Girzheva, O. (2019). Procedure of Identifying of the Parameters of the Model of Management of Technological Innovations in Economic Systems, 2019 IEEE International Scientific-Practical Conference Problems of Infocommunications, Science and Technology (PIC S\&T), Kyiv, Ukraine, 2019, pp. 324-328. doi: 10.1109/PICST47496.2019.9061259

[13] Daliak N. (2019) Research of the system of relationship with contractors as an element of evaluation of the efficiency of the activity of the enterprise. Journal of V.N. Karazin Kharkiv National University Series "International Relations. Economics. Country Studies. Tourism", 9, 100-108 doi: 10.26565/2310-9513-2019-912 
[14] Kuznetsov, A., Kavun, S., Smirnov O., Babenko, V., Nakisko, O., Kuznetsova, K. (2019). Malware Correlation Monitoring in Computer Networks of Promising Smart Grids. 2019 IEEE 6th International Conference on Energy Smart Systems, ESS 2019 Proceedings, No.. 8764228, 2019, pp. 347-352. DOI: 10.1109/ESS.2019.8764228

[15] Malyarets, L. M., Babenko, V. O., Nazarenko, O. V., Ryzhikova, N. I. (2019). The Modeling of Multi-criteria Assessment Activity in Enterprise Management, International Journal of Supply Chain Management, vol. 8, no. 4, pp. 997-1004.

[16] Krasnobaev V., Kuznetsov A., Babenko V., Denysenko M., Zub M. and Hryhorenko V. The Method of Raising Numbers, Represented in the System of Residual Classes to an Arbitrary Power of a Natural Number. 2019 IEEE 2nd Ukraine Conference on Electrical and Computer Engineering (UKRCON), July 2-6, Lviv, Ukraine, 2019, pp. 1133-1138. DOI: 10.1109/UKRCON.2019.8879793I

[17] Hrabovskyi, Y., Babenko, V., Al'boschiy, O., Gerasimenko, V. (2020). Development of a Technology for Automation of Work with Sources of Information on the Internet. WSEAS Transactions on Business and Economics, Vol. 17 (25), pp. 231-240. doi: $10.37394 / 23207.2020 .17 .25$

\section{ACKNOWLEDGEMENT}

We would like to thank all the reviewers for their thoughtful comments and efforts towards improving our manuscript. We revised the manuscript with special attention to the comments that we received from 3 reviewers that they were experts, specialist in the area of our paper. 